\title{
THE EUROPEAN EXPRESSION OF INTEREST FOR HIGH PURITY U-233 MATERIALS
}

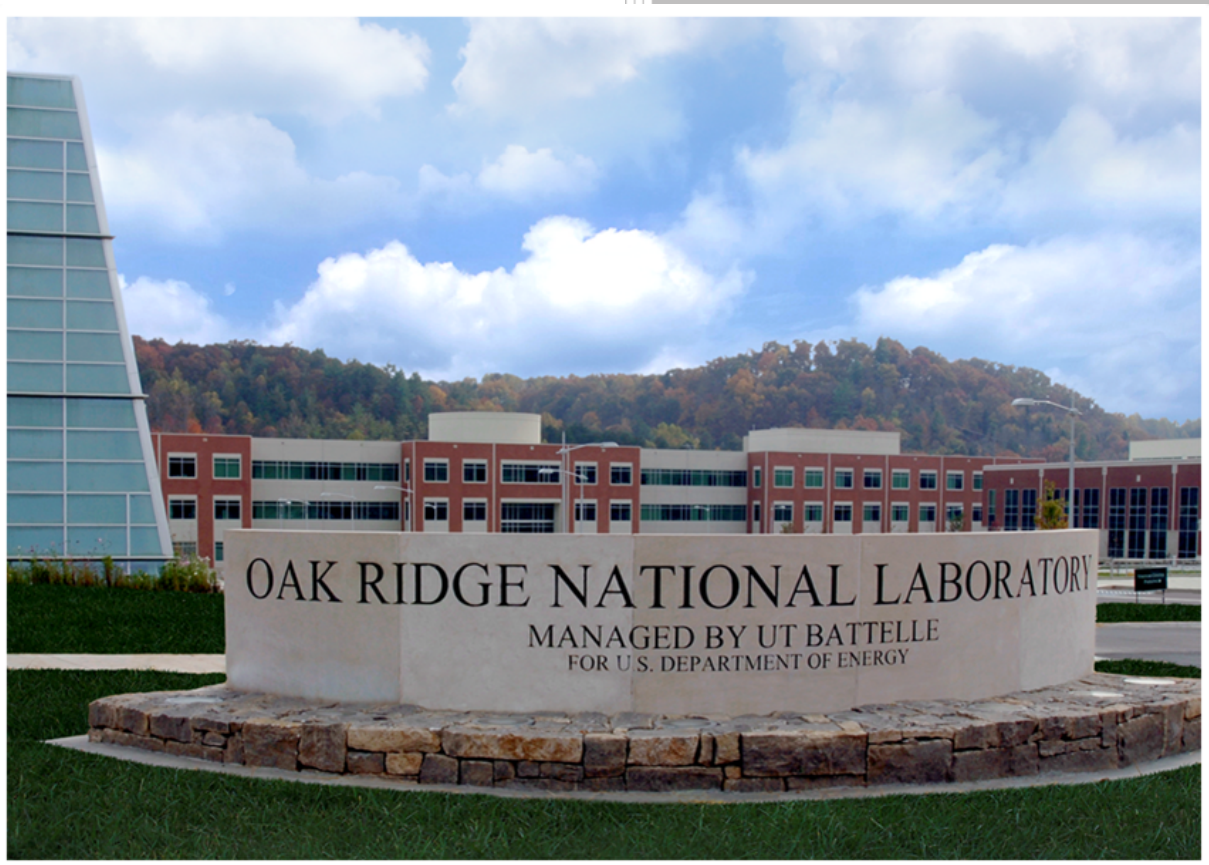

\section{Approved for public release.}

Distribution is unlimited.

Joseph M. Giaquinto James R. Younkin

April 2017 


\title{
DOCUMENT AVAILABILITY
}

Reports produced after January 1, 1996, are generally available free via US Department of Energy (DOE) SciTech Connect.

Website http://www.osti.gov/scitech/

Reports produced before January 1, 1996, may be purchased by members of the public from the following source:

\author{
National Technical Information Service \\ 5285 Port Royal Road \\ Springfield, VA 22161 \\ Telephone 703-605-6000 (1-800-553-6847) \\ TDD 703-487-4639 \\ Fax 703-605-6900 \\ E-mail info@ntis.gov \\ Website http://www.ntis.gov/help/ordermethods.aspx
}

Reports are available to DOE employees, DOE contractors, Energy Technology Data Exchange representatives, and International Nuclear Information System representatives from the following source:

Office of Scientific and Technical Information

PO Box 62

Oak Ridge, TN 37831

Telephone 865-576-8401

Fax 865-576-5728

E-mail reports@osti.gov

Website http://www.osti.gov/contact.html

This report was prepared as an account of work sponsored by an agency of the United States Government. Neither the United States Government nor any agency thereof, nor any of their employees, makes any warranty, express or implied, or assumes any legal liability or responsibility for the accuracy, completeness, or usefulness of any information, apparatus, product, or process disclosed, or represents that its use would not infringe privately owned rights. Reference herein to any specific commercial product, process, or service by trade name, trademark, manufacturer, or otherwise, does not necessarily constitute or imply its endorsement, recommendation, or favoring by the United States Government or any agency thereof. The views and opinions of authors expressed herein do not necessarily state or reflect those of the United States Government or any agency thereof. 


\title{
LETTER REPORT
}

\section{THE EUROPEAN EXPRESSION OF INTEREST FOR HIGH PURITY U-233} MATERIALS

\author{
Joseph M. Giaquinto \\ James R. Younkin \\ Chemical Sciences Division, Oak Ridge National Laboratory
}

April 2017

Prepared for the

U.S. Department of Energy

under contract DE-AC-00OR22725

Prepared by

OAK RIDGE NATIONAL LABORATORY

Oak Ridge, Tennessee 37831-6223

managed by

UT-BATTELLE, LLC 


\section{CONTENTS}

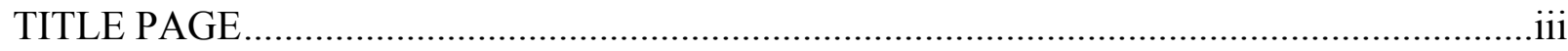

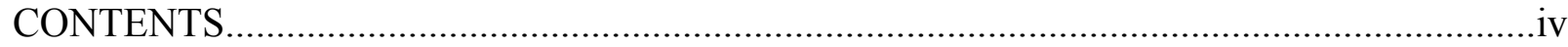

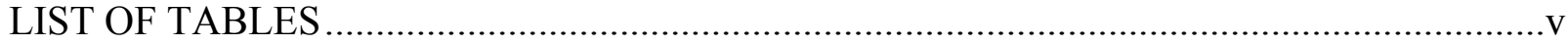

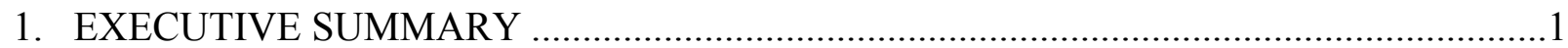

2. INITIAL SURVEY TO DETERMINE NEED .............................................................

3. CURRENT APPLICATIONS FOR 233U WITH U.S. SPONSORSHIP ...........................1

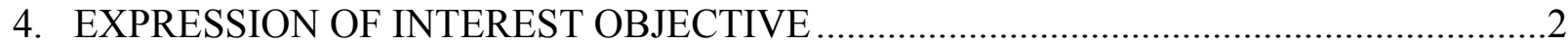

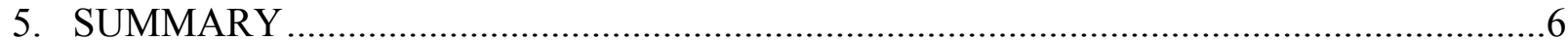

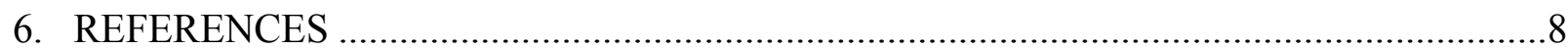

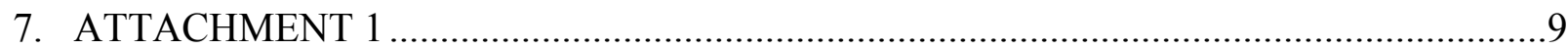




\section{LIST OF TABLES}

Table $1 \quad$ Summary of high-purity 233U materials inventory and U.S. sponsors.......................2

Table $2 \quad$ Summary of European responses and material requested .......................................... 4 


\title{
THE EUROPEAN EXPRESSION OF INTEREST FOR HIGH PURITY U-233 MATERIALS
}

\author{
Joseph M. Giaquinto \\ James R. Younkin
}

April 2017

\section{EXECUTIVE SUMMARY}

The purpose of this letter report is to document the response for an Expression of Interest (EOI) sent to the European Safeguards and research and development (R\&D) scientific communities for the distribution of small amounts of high purity ${ }^{233} \mathrm{U}$ materials for use in safeguards, nonproliferation, and basic $\mathrm{R} \& \mathrm{D}$ in the nuclear disciplines. The intent for the EOI was to gauge the level of international interest for these materials from government and research institutions with programmatic missions in the nuclear security or nuclear R\&D arena. The information contained herein is intended to provide information to assist key decision makers in DOE as to the ultimate disposition path for the high purity materials currently being recovered at Oak Ridge National Laboratory (ORNL) and only those items for which there is no United States (U.S.) sponsor identified.

\section{INITIAL SURVEY TO DETERMINE NEED}

Late in 2011, the U.S. Department of Energy/National Nuclear Security Administration Office of Defense Nuclear Nonproliferation (DNN) commissioned ORNL to conduct a study to determine and quantify the need for preserving high-purity ${ }^{233} \mathrm{U}$ with the initial original intent to replenish certified tracers used in uranium assays by Isotope Dilution Mass Spectrometry (IDMS). The study mainly examined the gap between supplies and demand to meet domestic needs only. Gaps associated with international safeguards and nonproliferation activities were extrapolated using the information gathered from the U.S. responses. The 2011 study found that the total needs, which included a strategic reserve, to be $\sim 850 \mathrm{~g}$ of ${ }^{233} \mathrm{U}$ over the next 50 years. Ultimately, approximately 1 kilogram of the purest materials were identified and rescued from down blending.

\section{CURRENT APPLICATIONS FOR 233U WITH U.S. SPONSORSHIP}

Current domestic applications, for which $\sim 270$ grams of the ${ }^{233} \mathrm{U}$ materials are being used, are well documented in Ref. 1. Reference 1 summarizes the programs as:

- comparative spiking standards for uranium analysis (also mentioned above),

- gamma spectrometry standards for nondestructive assay (NDA) of fissile ${ }^{233} \mathrm{U}$,

- alpha-emitting progeny in support of cancer therapy clinical trials (although progeny recovered from much larger amounts of ${ }^{233} \mathrm{U}$ would be useful), and

- other research and development, including micro-calorimetry

Reference 1 also discusses requests that have been made to date for small (gram or sub-gram) quantities of ${ }^{233} \mathrm{U}$ to support ongoing or planned research. These include: 
- gram quantity to study the low-energy nuclear isomeric state of ${ }^{229} \mathrm{Th}$,

- milligram amounts to study spectroscopy and calorimetry techniques at microscopic levels, and

- sealed sources as teaching tools at domestic university nuclear engineering centers.

Table 1 below summarizes the information from the report at a high level and includes information for the two largest items currently on hold (neither has a U.S. sponsor). It should be noted that the total amount of ${ }^{233} \mathrm{U}$ listed in the table are estimates only. Also, this is not a total listing of the ${ }^{233} \mathrm{U}$ items as some of the smallest items by mass are not included.

Table 1. Summary of high-purity ${ }^{233} \mathrm{U}$ materials inventory and U.S. sponsors

\begin{tabular}{|l|l|l|}
\hline \multicolumn{1}{|c|}{$\begin{array}{c}\text { Range of Purity } \\
\text { (wt. fraction) }\end{array}$} & $\begin{array}{c}\text { Total } \\
\text { Amount of } \\
\mathbf{2 3 3 U} \text { (g) }\end{array}$ & \multicolumn{1}{|c|}{ End-user Custody } \\
\hline $0.9999-0.9998$ & 98 & U.S. end-user custody \\
\hline 0.9998 & 110 & U.S. end-user custody \\
\hline 0.9976 & 75 & $\begin{array}{l}\text { 5 g U.S. end-user custody } \\
\text { 70 g No end-user. Currently under } \\
\text { NNSA project code }\end{array}$ \\
\hline 0.9990 & 64 & U.S. end-user custody \\
\hline $0.9946-0.995$ & 140 & $\begin{array}{l}\text { No end-user. Currently under NNSA } \\
\text { project code }\end{array}$ \\
\hline 0.995 & 442 & $\begin{array}{l}\text { Two large items on hold. No end-user. } \\
\text { Currently under NNSA project code }\end{array}$ \\
\hline
\end{tabular}

It can be seen from the information in Table 1 that of the items actively being processed at ORNL, 277 grams have a final disposition path and are under control of a U.S. sponsor. The remaining 210 grams do not have an end user identified and is currently under project funding by NNSA. In addition, there are 442 grams on hold with no end user identified.

\section{EXPRESSION OF INTEREST OBJECTIVE}

The EOI was drafted by a joint effort by Oak Ridge National Laboratory, through the sponsorship of the NNSA Office of Defense Nuclear Nonproliferation (NA-22), and the 2016 chairperson for the European Safeguards Research and Development Association's (ESRDA) Working Group on Techniques and Standards for Destructive Analysis (DA). The final approved EOI (Attachment 1) was sent to the European scientific community on November 16, 2016 via email.

It was clearly communicated to the European community that acceptable uses for consideration for the high purity material is defined within the project scope as part of a presentation given at the 2016 ESRDA DA Users Group Meeting held 26 May 2016 in Luxembourg and included in the EOI. They are broadly described as: 
- characterizations for special nuclear material production and activities,

- characterizations for international special nuclear material accountability, and

- Support programs which advance multi-disciplinary and cross-functional technology and research needs in the nuclear disciplines (i.e., chemistry, physics and engineering).

These guidelines will ensure that as the final disposition paths are agreed upon, this precious and irreplaceable material will only be used, at the approval of DOE, for the benefit of national and international nuclear security needs and advancement of research in the nuclear disciplines.

The objective for the EOI was to provide the NNSA sponsor with a list of international users and their institutions which were not given the opportunity to respond to the original 2011 study and to avoid unwanted long term storage for those materials which currently do not have a U.S sponsor. It should be noted that long term storage may still be considered as the ultimate disposition path depending on the benefit to the DOE for storing such materials for future missions. The intent of this particular exercise was merely to identify immediate needs internationally which may be favorable to the mission of DOE such that those needs can be properly vetted. This listing of international interests provides information in addition to the already established needs identified for U.S. programs in Table 1.

Table 2 summarizes the response from the EOI with the institutions listed and the materials desired. When included in the responses a brief description of the intended applications is also given. When a mass of a material was specified it is included it is table (grams). If no amount was specified, an " $\mathrm{X}$ " is used to indicate interest. 
Table 2. Summary of European responses and material requested (unit for the amounts shown is gram)

\begin{tabular}{|c|c|c|c|c|c|c|}
\hline Institution & Country & $\begin{array}{c}\text { Wt. } \\
\text { Fraction } \\
{ }^{233} \mathrm{U} \\
0.9999\end{array}$ & $\begin{array}{c}\text { Wt. Fraction } \\
{ }_{233} \mathrm{U} \\
0.9998\end{array}$ & $\begin{array}{l}\text { Wt. Fraction } \\
{ }^{233} U \\
0.9976-0.998\end{array}$ & $\begin{array}{c}\text { Wt. Fraction } \\
{ }^{233} \mathrm{U} \\
0.994-0.995\end{array}$ & Application \\
\hline $\begin{array}{l}\text { National Physics Laboratory } \\
\text { (NPL) }\end{array}$ & England & & 0.25 & & & $\begin{array}{l}\text { Forensics and } \\
\text { safeguards, nuclear time } \\
\text { measurements, } \\
\text { environmental } \\
\text { metrology, improved } \\
\text { decay data for }{ }^{233} \mathrm{U} \text { and } \\
\text { 229Th. }\end{array}$ \\
\hline Sellafield Ltd & England & & & & 40 & $\begin{array}{l}\text { Decommissioning of the } \\
\text { aged plants and } \\
\text { facilities. Mass } \\
\text { Spectrometry tracer for } \\
\text { IDMS. }\end{array}$ \\
\hline $\begin{array}{l}\text { School of Earth and } \\
\text { Environmental Sciences, } \\
\text { University of Portsmouth }\end{array}$ & England & 0.1 & & 0.1 & & IDMS tracer \\
\hline $\begin{array}{l}\text { European Commission/Joint } \\
\text { Research Centre Karlsruhe }\end{array}$ & Germany & $\mathrm{X}$ & $\mathrm{X}$ & $\mathrm{X}$ & $\mathrm{X}$ & $\begin{array}{l}\text { Application not } \\
\text { expressed in the EOI }\end{array}$ \\
\hline $\begin{array}{l}\text { Institute of Nuclear } \\
\text { Chemistry and Technology }\end{array}$ & Poland & & $\mathrm{X}$ & $\mathrm{X}$ & $\mathrm{X}$ & $\begin{array}{l}\text { Methods of measuring } \\
\text { uranium isotopes, trace } \\
\text { elements determination, } \\
\text { radiochemical separation } \\
\text { and production of CRMs } \\
\text { for inorganic trace } \\
\text { analysis. }\end{array}$ \\
\hline $\begin{array}{l}\text { IAEA Safeguards Analytical } \\
\text { Laboratory (SAL) }\end{array}$ & Vienna & 0.1 & 0.1 & 20 & 10 & $\begin{array}{l}\text { Getting at least } 10 \mathrm{~g} \text { of } \\
\text { U-233 material would be } \\
\text { beneficial to preserve it } \\
\text { for future IAEA needs, } \\
\text { but it does not need to } \\
\text { be of highest isotopic } \\
\text { purity. Therefore, items } \\
\# 4-\# 10 \text { and \#11-\#20 } \\
\text { would be of sufficient } \\
\text { quality for our use - we } \\
\text { would prefer U- } 233 \\
\text { metal pellets/pieces, if } \\
\text { possible smaller in size } \\
\text { for ease of handling. } \\
\text { High purity Item \#1 and } \\
\text { Item \#2 would be of } \\
\text { interest as IDMS spikes } \\
\text { for low-level } \\
\text { environmental samples. } \\
100 \text { mg per item would } \\
\text { be sufficient. }{ }^{1}\end{array}$ \\
\hline
\end{tabular}




\begin{tabular}{|c|c|c|c|c|c|c|}
\hline $\begin{array}{l}\text { Institution } \\
\text { (Cont'd.) } \\
\end{array}$ & \begin{tabular}{|l|} 
Institution \\
(Cont'd.) \\
\end{tabular} & $\begin{array}{c}\text { Wt. } \\
\text { Fraction } \\
\text { 233U } \\
\text { 0.9999 } \\
\text { (Cont'd.) } \\
\end{array}$ & $\begin{array}{c}\text { Wt. } \\
\text { Fraction } \\
233 U \\
0.9998 \\
\text { (Cont'd.) } \\
\end{array}$ & $\begin{array}{c}\text { Wt. Fraction } \\
\text { 233U } \\
0.9976-0.998 \\
\\
\text { (Cont'd.) } \\
\end{array}$ & $\begin{array}{c}\text { Wt. Fraction } \\
\text { 233U } \\
0.994-0.995 \\
\\
\text { (Cont'd.) } \\
\end{array}$ & $\begin{array}{l}\text { Application } \\
\text { (Cont'd.) } \\
\end{array}$ \\
\hline $\begin{array}{l}\text { National Nuclear Laboratory } \\
(\mathrm{NNL})\end{array}$ & England & & 20 & & & $\begin{array}{l}\text { large scale dried spikes } \\
\text { for irradiated fuels } \\
\text { IDMS analysis }\end{array}$ \\
\hline $\begin{array}{l}\text { Atomic Weapons } \\
\text { Establishment (AWE), } \\
\text { Nuclear Threat Reduction }\end{array}$ & England & & & 6 & 20 & $\begin{array}{l}\text { Nuclear forensic } \\
\text { programs at AWE }\end{array}$ \\
\hline $\begin{array}{l}\text { European Commission/Joint } \\
\text { Research Centre Geel } \\
\text { (previously Institute for } \\
\text { Reference Materials and } \\
\text { Measurements) }\end{array}$ & Belgium & $\mathrm{X}$ & $\mathrm{X}$ & $\mathrm{X}$ & $\mathrm{X}$ & $\begin{array}{l}\text { Nuclear Safety and } \\
\text { Security as well as } \\
\text { Standards for Nuclear } \\
\text { Safety, Security and } \\
\text { Safeguards. Interests in } \\
\text { items } 1 \text { - } 10 . \text { No } \\
\text { amounts specified. }^{1}\end{array}$ \\
\hline $\begin{array}{l}\text { Natural Environment } \\
\text { Research Council (NERC) } \\
\text { Isotope Geosciences } \\
\text { Laboratory }\end{array}$ & England & & $\mathrm{X}$ & & $\mathrm{X}$ & $\begin{array}{l}\text { National geosciences } \\
\text { facility and although we } \\
\text { only require small } \\
\text { quantities of tracers for } \\
\text { our work, high purity } \\
\text { 233U is important. } \\
\text { ORNL initiatives } \\
\text { relating to recovery and } \\
\text { production of highly } \\
\text { enriched 229Th would } \\
\text { be of great interest to us } \\
\text { and others in the U- } \\
\text { series geochronology } \\
\text { community. We } \\
\text { specialize in high } \\
\text { precision U isotope } \\
\text { measurements of } \\
\text { terrestrial geological } \\
\text { materials, meteorites, } \\
\text { and environmental } \\
\text { samples (e.g. urine, } \\
\text { soil). Regarding the } \\
\text { exact form of the } 233 \mathrm{U} \text {, } \\
\text { metal or oxide starting } \\
\text { materials dissolved in } \\
\text { high-purity nitric acid } \\
\text { would be attractive to } \\
\text { small users, and metal or } \\
\text { oxide necessary to those } \\
\text { responsible for making } \\
\text { new gravimetrically- } \\
\text { calibrated tracers for } \\
\text { wider distribution, as } \\
\text { was done for the very } \\
\text { successful, but now } \\
\text { limited supply IRMM } \\
3636 \text { tracer, widely used } \\
\text { for U-series } \\
\text { geochronology and } \\
\text { high-precision } 235 \mathrm{U}- \\
\text { 238U measurements. }\end{array}$ \\
\hline $\begin{array}{l}\text { Canadian Nuclear Labs } \\
\text { (CNL) }\end{array}$ & Canada & $\mathrm{X}$ & $\mathrm{X}$ & $\mathrm{X}$ & & $\begin{array}{l}\text { Production and Analysis } \\
\text { of Reference Materials. }\end{array}$ \\
\hline
\end{tabular}




\begin{tabular}{|c|c|c|c|c|c|c|}
\hline $\begin{array}{l}\text { Institution } \\
\text { (Cont'd.) }\end{array}$ & \begin{tabular}{|} 
Institution \\
(Cont'd.) \\
\end{tabular} & $\begin{array}{c}\text { Wt. } \\
\text { Fraction } \\
233 \mathrm{U} \\
0.9999 \\
\\
\text { (Cont'd.) }\end{array}$ & $\begin{array}{c}\text { Wt. } \\
\text { Fraction } \\
233 \mathrm{U} \\
\mathbf{0 . 9 9 9 8} \\
\\
\text { (Cont'd.) }\end{array}$ & $\begin{array}{c}\text { Wt. Fraction } \\
\text { 233U } \\
0.9976-0.998 \\
\text { (Cont'd.) }\end{array}$ & $\begin{array}{c}\text { Wt. Fraction } \\
\text { 233U } \\
0.994-0.995 \\
\\
\text { (Cont'd.) }\end{array}$ & $\begin{array}{l}\text { Application } \\
\text { (Cont'd.) }\end{array}$ \\
\hline $\begin{array}{l}\text { Canadian Nuclear Labs } \\
\text { (CNL) }\end{array}$ & Canada & $\mathrm{X}$ & $\mathrm{X}$ & $\mathrm{X}$ & $\mathrm{X}$ & $\begin{array}{l}\text { Here at CNL, we are } \\
\text { currently processing a } \\
\text { small, aged ( } 40 \text { year) } \\
\text { stock pile of } 233 \mathrm{UO} 2 \\
(400 \mathrm{~g}) \text { for the purpose } \\
\text { of removing the } \\
\text { daughter decay product } \\
\text { Th-229. This material } \\
\text { will then be used to } \\
\text { expand our Th/Ac } \\
\text { generator as part of our } \\
\text { Health and Biology } \\
\text { program for work in } \\
\text { Targeted Alpha } \\
\text { Therapy. }\end{array}$ \\
\hline CEA/DEN/DRCP/CETAMA & France & & $\mathrm{X}$ & $\mathrm{X}$ & & $\begin{array}{l}\text { CETAMA, the French } \\
\text { CEA commission for the } \\
\text { establishment of } \\
\text { analytical methods is } \\
\text { interested by your highly } \\
\text { purified U233 materials, } \\
\text { in the framework of its } \\
\text { CRM and ILC activities } \\
\text { in the nuclear fuel cycle. }\end{array}$ \\
\hline CEA & France & & $\mathrm{X}$ & $\begin{array}{l}\text { X: Metal } \\
\text { pellets only } \\
\text { from one of } \\
\text { the items. }\end{array}$ & & $\begin{array}{l}\text { Precise } U \text { analysis in } \\
\text { forensic sciences }\end{array}$ \\
\hline $\begin{array}{l}\text { University of Jyväskylä, } \\
\text { Department of Physics }\end{array}$ & Finland & & & & 0.3 & $\begin{array}{l}\text { Limited rad facilities } \\
\text { (U-232 may be issue?). } \\
\text { R\&D to determine ultra- } \\
\text { low -lying isomeric state } \\
\text { in Th-229. Also, studies } \\
\text { of charged-particle } \\
\text { induced fission for } \\
\text { actinides using U233 as } \\
\text { target. }\end{array}$ \\
\hline $\begin{array}{l}\text { Institut Laue-Langevin, } \\
\text { Nuclear and Particle Physics } \\
\text { group }\end{array}$ & France & 0.05 & 0.03 & & & $\begin{array}{l}\text { Application not } \\
\text { expressed in the EOI }\end{array}$ \\
\hline $\begin{array}{l}\text { Korea Atomic Energy } \\
\text { Research Institute (KAERI) }\end{array}$ & $\begin{array}{l}\text { South } \\
\text { Korea }\end{array}$ & $\mathrm{X}$ & $\mathrm{X}$ & & & $\begin{array}{l}\text { Application not } \\
\text { expressed in the EOI }\end{array}$ \\
\hline
\end{tabular}

" $\mathrm{X}$ " indicates interest in this class of material but no specific quantity required/requested.

${ }^{1}$ Item numbers are those listed in the EOI. See Attachment 1.

\section{SUMMARY}

Overall seventeen responses were received from sixteen institutions, two independent responses were received from Canadian Nuclear Labs from separate organizations. Eight responses contained specific weights for items which totaled slightly greater than 117 grams. Nine 
responses identified a need for items of certain purities but no weights were included. As noted, these are designated with an " $\mathrm{X}$ " in Table 2.

Four requests were for large amounts of material totaling $\sim 116$ grams. Sellafield requested 40 grams to support decommissioning of legacy nuclear sites for which they will use the material for a tracer for mass spectrometry. From this information, it is assumed it will be used as large scale dried spikes in which larger amounts of a spike material is used to quantify uranium content in an unknown bulk sample. Similarly, NNL requested 20 grams for the same purpose, but their samples are identified as irradiated fuels. AWE requested 26 grams of the lower purity material for forensics. From the amount requested, it is possible that they are planning to produce an in-house working reference material to meet their need. The IAEA SAL requested smaller amounts of the two most pure items and 30 grams of the last two. In their response, they specifically mentioned preservation of at least 10 grams for future IAEA needs.

Four of the responses (NPL, University of Portsmouth, University of Jyväskylä, and Institut Laue-Langevin) listed weights totaling slightly over 1 gram. For those, the use has been identified as either forensics/tracer for IDMS or research. For those institutions requesting small amounts of material designated to be used for forensics as an IDMS tracer, it is believed that they did not recognize that the material distributed would not be certified for uranium assay or isotopics. This is information that must be confirmed in future communications if the collaboration to transfer material is approved.

Of nine responses with no specific weights identified, it is surmised that for JRC Geel (the European producer of reference materials) and others identifying producing reference materials, the need would be for tens of grams each. This would be the case four of these nine responses. Simarily, CNL identified a need for ${ }^{229} \mathrm{Th}$ production and $\mathrm{Th} / \mathrm{Ac}$ generators. It is assumed that tens to hundreds of grams of material would be desired to meet that need. Of the remaining four, two responses identified R\&D efforts which small amounts of material would satisfy. The last two, JRC Karlsruhe and KAERI, did not identify any specific need only the items desired.

It should be noted that the EOI was sent with a material form listed for the items. Some of the responses did identify a specific form desired (metal over oxide). Currently at ORNL, it is not intended to preserve items in metallic form. All recovered materials are being mixed by batches of isotopic purity after dissolution, then converted to a free-flowing oxide for distribution or storage. If this is to change, it needs to be stated as soon as possible. The exception is item \#1 which will remain as a metal foil for the U.S. end-user.

In summary, a total of $\sim 117$ grams of material was specifically identified in the responses to the EOI. Possibly another 100-200 grams could be distributed based on the needs expressed by the institutions which did not provide specific amounts. However, amounts must be confirmed for those responses. Further communication is needed to clarify which isotopic purities will be available for distribution to the European community and in what form they will be distributed. 


\section{REFERENCES}

1. Preserving High Purity Uranium-233, Alan Krichinsky, Joe Giaquinto, and Doug Canaan Journal of Radioanalytical and Nuclear Chemistry, Special Issue: MARC X, Volume 307, Number 3, March 2016. 


\section{ATTACHMENT 1 \\ Working Group on Techniques and Standards for Destructive Analysis (WGDA)}

Subject: Expression of Interest in the ORNL rescue of high purity ${ }^{233} \mathrm{U}$ materials

Dear colleague,

During our last WG meeting in Luxembourg Joe Giaquinto from ORNL gave a presentation about the rescue of high enriched ${ }^{23} \mathrm{U}$ material. This material was produced in the past from $\mathrm{ThO}_{2}$ targets (960 tonnes) by irradiation. At that time about 1.5 tonnes of highly enriched ${ }^{233} \mathrm{U}$ material was produced. The Department of Energy (DoE) plan is to down blend the material and dispose it. In 2011 a study was conducted to rescue some of this high purity material (purity above $99 \%$ ) from down blending. As a result, about $1 \mathrm{~kg}$ of this material in the form of metal pieces, foils, pellets, $\mathrm{U}_{3} \mathrm{O}_{8}$ powder is being preserved at ORNL to satisfy future needs.

The two materials with the highest purity were set aside as candidates for future CRMs to be used for precise uranium analyses. Other applications will include the use of ${ }^{229} \mathrm{Th}$ (daughter product of $233 \mathrm{U}$ ) for alpha therapy cancer research, counting standards, sealed sources as training devices and others. Repacking and stabilisation of all materials for compliant storage is foreseen. The materials for on-site use will be stored in liquid form, while for the off-site use; the material will be transformed into dried nitrate and stored in Savillex PFA vials. For long-term storage, the materials will be converted into oxide and stored in Swagelok bored-plug containers. The initial characterisation of a high-purity ${ }^{233 \mathrm{U}}$ spike for use in uranium analysis was carried out by NBL and ORNL (K. J. Mathew et al., Int. J. mass Spectrom., Vol 389, 2015, 4735). A portion of this UTHX-001 material will be made available for international reference material programmes.

Please find below the list of items being preserved 


\section{Ultra-Pure U-233 Items Being Preserved}

\begin{tabular}{|c|c|c|c|}
\hline Number & Form & Gram 233U & Wt\% Purity \\
\hline Item \#1 & Metal foil & 4 & 0.99996 \\
\hline Item \#2 & U308 powder & 126 & 1 \\
\hline Item \#3 & Metal pieces \& foils & 77 & 0.997660 \\
\hline Items \#4 - \#10 & $\begin{array}{l}\text { Metal pellets, pieces \& } \\
\text { foils; powders }\end{array}$ & 182 & $0.997-0.999$ \\
\hline Items \#11 - \#20 & $\begin{array}{l}\text { Metal pellets, pieces \& } \\
\text { foils; powders }\end{array}$ & 580 & $0.994-0.995$ \\
\hline TOTALS & 20 Items & 969 & All $>0.99$ \\
\hline
\end{tabular}

\section{All remaining high-quality $\mathbf{U}-233$ materials will be down-blended and disposed!}

In case you are interested in ultra-pure ${ }^{233} \mathrm{U}$ items from ORNL could you please fill in the questionnaire and indicate your name, affiliation and e-mail address.

Please return the questionnaire per email at the latest on 20 December 2016 directly to Joe Giaquinto:

giaquintojm@ornl.gov

We thank you very much for your cooperation

Best regards,

Rožle Jakopič and Eva Kovács-Széles

Vice-chair and chair DA working group

Expression of interest in ultra-pure ${ }^{23} \mathrm{U}$ items from ORNL

Name: 
Affiliation:

E-mail:

Please indicate in which item(s) you are interested
$\square$ Item \#1
$\square$ Item \#2
$\square$ Item \#3
$\square$ Item \#4 - \#10
$\square$ Item \#11 - \#20

Any comments:

The ESARDA WGDA by means of this questionnaire is only facilitating the Expression of Interest on behalf of the US-DOE.

ORNL is then to initiate further dialogue with the individual laboratories that have expressed interest. 